\title{
EVALUATION OF SPINOSAD AND IVERMECTIN AGAINST THREE OF STORED GRAIN INSECTS IN WHEAT GRAINS Sahar I. Ahmed ${ }^{1}$ and Hoda M. Nasr ${ }^{2}$ 1- Department of pesticides,Fac. of Agric.Kafr El-Sheikh Univ. 2- Plant control and environmental protection Fac. of Agric.Damanhour Univ.
}

\begin{abstract}
The present study was carried out to evaluate two naturalyte biocides, spinosad and ivermectin, one recommended chemical synthetic insecticide, malathion as reference against three important insects of stored grain, Sitophilus oryzae, Rhyzopertha dominica and Tribolium castaneum. Results obtained show that rates of spinosad or ivermectin from 50-150 ppm and rates of malathion from 1-4 ppm completely prevented emergence of adults of S.oryzae and followed that increase the reduction of progeny to $100 \%$. R.dominica has the same trend with S.oryzae, but the R.dominica was more susceptible to biocides and insecticide tested than S.oryzae, which gave high mortality ranged from $81-100 \%$ at all concentrations. T.castaneum was more tolerant than the other tested insects. At the all rates of tested materials, the percentage loss weight of wheat decreased in comparison with control. In generally, $R$.dominica was the most susceptible to the tested materials followed by S.oryzae and T.castaneum . S.oryzae adults exposed to wheat grain diet received half-dose of 50 ppm spinosad or ivermectin, separately gave 96 and $88 \%$ mortality after two weeks of exposure, while the one-third dose gave 90 and $63 \%$ mortality. The high levels of both spinosad or ivermectin nearly completely prevented the $F_{1}$ progeny of S.oryzae in half and one third dose. R.dominica was higher affected than S.oryzae at the same levels of spinosad and ivermectin where spinosad at the all levels of half dose completely prevented the $F_{1}$ progeny of $R$.dominica while with the one-third dose the $\%$ reduction values ranged from 82.3 to $100 \%$.
\end{abstract}

\section{INTRODUCTION}

Contact insecticides, alongside with fumigants, are still most widely used to control insects of stored products. They were introduced at the end of the $1960 \mathrm{~s}$, and organophosphates were the most frequently used group of these insecticides at the beginning, while pyrethroids have been used more intensvely in the latest period (White and Leesch,1996; Kljajic, 2008;and MacBean, 2012). The indiscriminate use of pesticides for the management of this notorious insect is not only hazardous to human beings but responsible for disturbing the eco-system as well. The use of these synthetic insecticide have also resulted resistance in $T$. cateneum against these insecticides. Shakoori et al. (1998) and Lessard et al. (1998) have also reported resistance in $T$. castaneum against synthetic pyrethroids, e.g., cypermetrin, deltamethrin, cyfluthrin, fenvalerate and some juvenile hormone analogues. The hazardous nature of fumigants has made it obligatory to test insecticides bearing novel modes of action, e.g., abamectin, spinosad, indoxacarb, azadirachtin and hydrocarbon against $T$. castaeum to minimize the risks and losses 
Daglish and Nayak (2006) evaluated the persistence and efficacy of spinosad against Rhyzopertha dominica (F.) in wheat stored for 9 months. Spinosad applied at 0.5 or $1 \mathrm{mg} \mathrm{kg}-1$ was effective for 9 months with $100 \%$ adult mortality after 14 days of exposure and no live F1 adults produced.

One of the ways to manage the problem of resistance of stored product insects to different insecticides and to alleviate selection pressure in practice is to introduce new insecticides.

The latest studies have shown that natural insecticides spinosad and abamectin are as effective as the contact insecticides used so far (Fang et al., 2002. Arthur et al., 2004; Athanassiou et al., 2008 ; Kavallieratos et al., 2009; Andrie et al., 2011; and Wakil et al., 2013) .

Spinosad is toxic by ingestion and contact,and has a unique mode of action on the insect nervous system at the nicotinic acetylcholine and $\mathrm{V}$ aminobutyric acid (GABA) receptors sites(Bret etal.,1997;Salgado 1998).

Spinosad is based on the etabolites of the bacterium Saccharopolyspora Spinosad Mertz and Yao(Bacteria:Actinobacteriadae). Spinosad is a broadspectrum insecticide with low mammalian toxicity, and it is effective against many stored- grain insect species( Fang etal.,2002b;Nayak etal.,2005).

Moreover, Spinosad gives excellent residual control,which makes it an ideal protectant for stored grain commodities( Fang etal.,2002a ; Fang And Subramanyam,2003)

In recent years, the toxicity of insecticides to humans and wildlife has caused much public concern, and led to the use of more target-specific chemicals (Paoletti and Pimental 2000). Therefore, the present study investigated the efficiency of Ivermectin and Spinosad relative to recommended malation insecticide against three important insects of stored grain, S.oryzae, T.castaneum and R.dominica with the respect to adult mortality, \% reduction in progny and \% loss of wheat grain weight by two different methods of mixing with media at two periods of exposure.

\section{MATERIALS AND METHODS}

\section{Materials \\ Insects :-}

Three important coleopteran stored grain insects were assessed in the current investigation, Lesser grain borer, R.dominica (F.) (Bostrychidae: Coleoptera), rice weevil, S.oryzae (L.) (Curculionidae: Coleoptera) and red flour bettle, T.castaneum (Herbst) (Tenebrionidae: Coleoptera). The original stock culture of the three insects were obtained from stored

product pest laboratory, Plant Protection Research Institute, Sakha Agricultural Research Station.

\section{R.dominica:}

Insects were reared on wheat grains, cleaned from dusts, husks and other inert materials and sterilized by heating at $60^{\circ} \mathrm{C}$ for one hour, then grains were put in glass jars each containing $400 \mathrm{~g}$ of wheat and provided with 100-200 adult insects. Jars were covered with muslin cloth secured with 
elastic rubber bands and placed under laboratory conditions of $30 \pm 2^{\circ} \mathrm{C}$ and $65 \pm 5 \%$ R.H. The newly emerged adults (1-2weeks old) were used for tests.

S.oryzae:

S.oryzae (Egyptian strain) was obtained from the Department of Stored Products Pests Control, Plant Protection, Reaserch Institute Sakha Kafr ElShiekh. This strain was continuosly reared free of insecticidal contamination for several years at $30 \pm 2^{\circ} \mathrm{C}$ and $70 \pm 5$ relative humidity $(\mathrm{RH})$. The cultures were maintained under the same conditions in the Pesticide Department, Faculty of Agriculture, Kafr-El-Shiekh University, Egypt and 200-400 adults from the pervious culture were added in $1000 \mathrm{ml}$ glass jars containing 400 gram of wheat as a culture medium. The mouth of the jars were covered with muslin cloth. Then, 7-14d old adults were used for experimental work.

\section{T.castaneum:}

Insects were reared on a mixture of wheat grain mixed with wheat flour. Grain were cleaned and sterilizes and put in glass jars each containing $400 \mathrm{gm}$ (30\% wheat flour) and provided with 100-200 adult insects. Jars were covered and placed under laboratory conditions of $30 \pm 2^{\circ} \mathrm{C}$ and $65 \pm 5 \%$ R.H. The newly emerged adults (1-2 weeks old) were used for different tests.

\section{Insecticides}

Tracer (Spinosad) (24\% S.C.)

Bacterial derived insecticide,mixture of spinosyn A and D,Copping and Menn(2002).

Ivon (Ivermectin) (1\% Injectable solution)

Invermectin : is synthesized from avermectin $B_{1}$ by reducing the 22,23double bond producing dihydro avermectin $B_{1 a}$ and dihydro avermectin $B_{1 b}$.

Avermectin $B_{1 a}\left(5-0\right.$-dimethyl avermectin $\left.A_{1 a}\right)$.

Avermectin $\quad B_{1 b}$ (5-0-dimethyl-25-de-(1-methyl propyl)-25-(1-methyl ethyl) avermectin $A_{1 a}$.

Malathion (57\% EC)

0,0-dimethyl-s-(1,2-dicarboxyethyl) ethylphosphorodi-thioate.

Effect of spinosad and ivermectin by common mixing on tested insects:

Batches of whole wheat grain were weighed $(20 \mathrm{gm})$ and placed in glass jars $(250 \mathrm{ml})$ for S.oryzae and R.dominica, or $20 \mathrm{~g}$ of cracked wheat grains for T.castaneum. The tested insecticides,(spinoad, ivermectin and malation) were diluted in water and added to the grains at rates which give the required concentrations $(10,50,100$ and $150 \mathrm{ppm})$ for spinosad and ivermectin and $(0.5,1,2$ and $4 \mathrm{ppm})$ for malathion, jars were shaken by hand and grains were allowed to dry at room temperature. Twenty unsexed adults of each insect (1-2 weeks old) were introduced to a jar containing treated grain, 3 replicates were set up for each treatment and control. Before introduction T.castaneum, part of wheat was ground to flower and returned to the jars after that, 10 adults of $S$. oryzae were transferred to the treated wheat grains which putted in a $85 \times 45 \mathrm{~mm}$ plastic jar. and kept at $30 \pm 2^{\circ} \mathrm{C}$ and $70 \pm 5 \mathrm{RH}$. relative humidity, according to the method described by Kestenholz et al. (2007). Mortality counts were recorded after 7 and 14 days and corrected by Abbott's formula (1925). The number of progeny was recorded 
after 2 months post-treatment. The reduction percentages in adult number after 2 months post-treatment were recorded and calculated according to the following equation of Tapondjou et al. (2002).

where ,

$$
\% I R=(C n-T n) 100 / C n,
$$

$\mathrm{Cn}$ is the number of newly emerged insects in the untreated (control) jar, Tn is the number of newly emerged insects in treatments. The Percentages of wheat weight loss were also recorded 2 months after treatment according to the equation of Harris and Lindblad (1978).

$$
\% \text { loss }=\frac{\text { Initial dry weight of seeds }- \text { seeds dry weight after } 2 \text { months }}{\text { Initial dry weight of seeds }} \times 100
$$

Effect of spinosad and ivermectin by modified mixing (mixture of untreated and treated wheat grain) on three tested insects :

The aim of this experiment is minimizing the pollution of grain during control of insects which attack the stored products using common mixing with media method, this method cause high contamination to treated grain, therefore modified method of mixing with diet was used in the present study. To carry out this modified method, two treatments were conducted as the following:

In the first treatment (half-dose): $10 \mathrm{gm}$ wheat grain was treated by spinosad or ivermectin with the required concentrations and allowed to dry at room temperature, then manually mixed with other untreated $10 \mathrm{gm}$ wheat grain to contain final concentration equal the half-dose.

In the second treatment (one-third dose), $10 \mathrm{gm}$ wheat grain treated by the same insecticides with the required concentrations, then were allowed to dry at room temperature, and manually mixed with other untreated $20 \mathrm{gm}$ wheat grain to contain final concentration equal one-third the used dose. In both treatments the mixture of treated and untreated wheat grain was transferred into glass jars $250 \mathrm{ml}$ each covered with muslin. Twenty insects of S.oryzae or R.dominica were confined with the first mixture (received halfdose). For the second mixture (received one-third-dose) thirty unsexed insects of both tested insects were confined. $20 \mathrm{gm}$ wheat grain for the first treatment and $30 \mathrm{gm}$ for the second treatment have no any insecticides were used as control. Three replicates of each treatment and control were set10 adults of $S$. oryzae and transferred to the treated wheat grains which putted in a $85 \times 45 \mathrm{~mm}$ plastic jar. and kept at $30 \pm 2^{\circ} \mathrm{C}$ and $70 \pm 5 \mathrm{RH}$. relative humidity, according to the method described by EL-Tawelah (2005). Mortality counts were recorded at 7 and 14 days post-treatment and corrected by Abbott's formula (1925). The number of progeny was recorded after 2 months post-treatment. The reduction percentages in adult number after 2 months post-treatment were recorded and calculated according the equation of Tapondjou et al. (2002)and the percentages of wheat weight loss were also recorded 2 months after treatment. Percentages of wheat weight loss were also recorded 2 months after treatment according to the equation of Harris and Lindblad (1978) as mentiond before. 


\section{Statistical Analysis}

Data obtained from the experiments were statistically analyzed using the method of analysis of variance( Duncan ,1955) one-way repeated measurement analysis of variance Duncan's multiple range test were used to separate means using SAS program (Version 6.12, SAS Institute Inc., Cary, USA).

\section{RESULTS AND DISCUSSION}

\section{Insecticidal activity of insecticides on adult insects S.oryzae, R.dominica and T.castaneum.}

A laboratory experiment was carried out to evaluate two naturalyte biocides, spinosad and ivermectin, one recommended chemical synthetic insecticide, malathion as reference against three important insects of stored grain, S.oryzae, R.dominica and T.castaneum. Results obtained in Table (1) show that rates of spinosad and ivermectin from 50-150 ppm and rates of malathion from 1-4 ppm completely prevented emergence of adult of S. oryzae and followed that increase the reduction of progeny to $100 \%$. Highly significant differences were found between treatments at rate of $10 \mathrm{ppm}$ for both spinosad, ivermectin and control concerned to the emergence of adults of S.oryzae. In addition, the concentration of $10 \mathrm{ppm}$ spinosad and ivermectin and $0.5 \mathrm{ppm}$ malathion caused $73.0,74.3$ and $78.9 \%$ reduction in progeny, respectively. There was varied response of S.oryzae against either tested biocides and chemical insecticide.

For R.dominica, data in Table (2) refer the same trend with S.oryzae, but the R.dominica was more susceptible to biocides and chemical insecticide tested than S.oryzae. Table (3) included the data of T.castaneum. From these results, T.castaneum was more tolerant than the other tested insects. At the all rates of tested materials, the percentage of loss weight of wheat decreased in comparison with control. In generally, R.dominica was the most susceptible to the tested materials followed by S.oryzae and T.castaneum. In this respect, type of tested species is an important factor. The chemical insecticide malathion was the most efficient agent as compared with the other tested toxic materials. In the present study, results refer to spinosad and ivermectin could be promising alternatives to malathion as protectant agent for stored grain insects control. The biocide, spinosad have low mammalian toxicity and rapid degradation in the environment (Thomposon et al.,2000). 
Table (1): Effect of insecticides on adults of S.oryzae using mixing with media at different indicated periods .

\begin{tabular}{|c|c|c|c|c|c|c|c|c|}
\hline \multirow[b]{2}{*}{ coumpounds } & \multirow[b]{2}{*}{ Conc.(ppm) } & \multicolumn{2}{|c|}{\begin{tabular}{|c|}
$\begin{array}{c}\text { \%Mortality } \\
\text { after }\end{array}$ \\
\end{tabular}} & \multicolumn{2}{|c|}{$\mathrm{LC}_{50}$} & \multirow{2}{*}{$\begin{array}{c}\text { No. of } \\
\text { emerged } \\
\text { adults } \\
\text { after } 2 \\
\text { months }\end{array}$} & \multirow{2}{*}{$\begin{array}{c}\% \\
\text { reduction } \\
\text { in F1 } \\
\text { progeny }\end{array}$} & \multirow{2}{*}{$\begin{array}{c}\begin{array}{c}\% \text { loss } \\
\text { of } \\
\text { wheat } \\
\text { grain } \\
\text { weight }\end{array} \\
\end{array}$} \\
\hline & & $\begin{array}{c}1 \\
\text { week }\end{array}$ & $\begin{array}{c}2 \\
\text { weeks }\end{array}$ & $\begin{array}{c}1 \\
\text { week }\end{array}$ & $\begin{array}{c}2 \\
\text { weeks }\end{array}$ & & & \\
\hline Spinosad & $\begin{array}{c}10 \\
50 \\
100 \\
150 \\
\end{array}$ & $\begin{array}{l}40 \\
63 \\
78 \\
93 \\
\end{array}$ & $\begin{array}{c}46 \\
79 \\
94 \\
100 \\
\end{array}$ & 17 & 12 & $\begin{array}{c}120.3 \mathrm{f} \\
0.0 \\
0.0 \\
0.0\end{array}$ & $\begin{array}{l}73.0 \mathrm{c} \\
100 \mathrm{a} \\
100 \mathrm{a} \\
100 \mathrm{a}\end{array}$ & \begin{tabular}{|c|}
$3.3 \mathrm{gh}$ \\
$2.9 \mathrm{hi}$ \\
$2.5 \mathrm{hi}$ \\
$1.4 \mathrm{i}$ \\
\end{tabular} \\
\hline Ivermectin & $\begin{array}{c}10 \\
50 \\
100 \\
150 \\
\end{array}$ & $\begin{array}{c}45 \\
76 \\
88 \\
100 \\
\end{array}$ & $\begin{array}{c}61 \\
88 \\
100 \\
100 \\
\end{array}$ & 12 & 7.2 & $\begin{array}{c}114.6 \mathrm{f} \\
0.0 \\
0.0 \\
0.0\end{array}$ & $\begin{array}{l}74.3 \mathrm{c} \\
100 \mathrm{a} \\
100 \mathrm{a} \\
100 \mathrm{a}\end{array}$ & \begin{tabular}{|c|}
$4.1 \mathrm{~g}$ \\
$3.4 \mathrm{gh}$ \\
$2.2 \mathrm{hi}$ \\
$1.8 \mathrm{hi}$ \\
\end{tabular} \\
\hline Malathion & $\begin{array}{c}0.5 \\
1 \\
2 \\
4\end{array}$ & $\begin{array}{l}50 \\
73 \\
83 \\
88\end{array}$ & $\begin{array}{l}76 \\
95 \\
93 \\
98\end{array}$ & 0.42 & 0.06 & $\begin{array}{c}94.0 \mathrm{~g} \\
0.0 \\
0.0 \\
0.0\end{array}$ & $\begin{array}{c}78.9 \mathrm{~b} \\
100 \mathrm{a} \\
100 \mathrm{a} \\
100 \mathrm{a}\end{array}$ & \begin{tabular}{|c|}
$5.6 \mathrm{e}$ \\
$3.3 \mathrm{gh}$ \\
$2.1 \mathrm{hi}$ \\
$1.4 \mathrm{i}$
\end{tabular} \\
\hline Control & 0 & 0 & 0 & & & $446.3 \mathrm{a}$ & & $72.1 \mathrm{a}$ \\
\hline
\end{tabular}

Mean followed by the same letters in the column are not significantly different $(P<0.05)$.

Table (2): Effect of insecticides on adults of R.dominica using mixing with media at different indicated periods .

\begin{tabular}{|c|c|c|c|c|c|c|c|c|}
\hline \multirow[b]{3}{*}{ Treatment } & \multirow[b]{3}{*}{ Conc.(ppm) } & \multirow{2}{*}{\multicolumn{2}{|c|}{$\begin{array}{c}\text { Mortality } \\
\%\end{array}$}} & \multirow{2}{*}{\multicolumn{2}{|c|}{$\mathbf{L C}_{50}$}} & \multirow{3}{*}{$\begin{array}{l}\text { No. of } \\
\text { emerged } \\
\text { adults } \\
\text { after } 2 \\
\text { months }\end{array}$} & \multirow{3}{*}{$\begin{array}{c}\% \\
\text { reduction } \\
\text { in } \mathrm{F1} \\
\text { progeny }\end{array}$} & \multirow{3}{*}{$\begin{array}{c}\text { \%loss of } \\
\text { wheat } \\
\text { grain } \\
\text { weight }\end{array}$} \\
\hline & & & & & & & & \\
\hline & & 1 & 2 & 1 & 2 & & & \\
\hline \multirow{4}{*}{ Spinosad } & 10 & 63 & 81 & \multirow{4}{*}{3.6} & \multirow{4}{*}{0.57} & 0.0 & $100 \mathrm{a}$ & $2.9 \mathrm{efg}$ \\
\hline & 50 & 81 & 86 & & & 0.0 & $100 \mathrm{a}$ & $2.0 \mathrm{gh}$ \\
\hline & 100 & 86 & 96 & & & 0.0 & $100 a$ & $1.3 \mathrm{hi}$ \\
\hline & 150 & 100 & 100 & & & 0.0 & $100 \mathrm{a}$ & $0.9 \mathrm{i}$ \\
\hline \multirow{4}{*}{ Ivermectin } & 10 & 75 & 83 & \multirow{4}{*}{1.0} & \multirow{4}{*}{0.8} & 0.0 & $100 \mathrm{a}$ & 3.4 ef \\
\hline & 50 & 85 & 91 & & & 0.0 & $100 a$ & 3.1 ef \\
\hline & 100 & 95 & 98 & & & 0.0 & $100 a$ & 2.8 efg \\
\hline & 150 & 96 & 100 & & & 0.0 & $100 \mathrm{a}$ & $2.0 \mathrm{gh}$ \\
\hline & & & & & & & & \\
\hline \multirow{4}{*}{ Malathion } & 0.5 & 53 & 81 & \multirow{4}{*}{0.41} & \multirow{4}{*}{0.22} & $108.3 \mathrm{c}$ & $67.6 \mathrm{~d}$ & 3.4 ef \\
\hline & 1 & 76 & 93 & & & 0.0 & $100 \mathrm{a}$ & $2.7 \mathrm{fg}$ \\
\hline & 2 & 85 & 100 & & & 0.0 & $100 a$ & $1.6 \mathrm{hi}$ \\
\hline & 4 & 93 & 100 & & & 0.0 & $100 a$ & $1.1 \mathrm{hi}$ \\
\hline Control & 0 & 0 & 0 & & & $335 a$ & & $76.0 \mathrm{a}$ \\
\hline
\end{tabular}

Mean followed by the same letters in the column are not significantly different $(P<0.05)$. 
Table (3): Effect of insecticides on adults of T.castaneum using mixing with media at different indicated periods.

\begin{tabular}{|c|c|c|c|c|c|c|c|c|}
\hline \multirow[b]{2}{*}{ coumpounds } & \multirow[b]{2}{*}{ Conc.(ppm) } & \multicolumn{2}{|c|}{$\begin{array}{c}\text { \%Mortality } \\
\text { after }\end{array}$} & \multicolumn{2}{|c|}{$\begin{array}{l}\mathbf{L C}_{50} \\
\text { after }\end{array}$} & \multirow{2}{*}{$\begin{array}{l}\text { No. of } \\
\text { emerged } \\
\text { adults } \\
\text { after } 2 \\
\text { months }\end{array}$} & \multirow{2}{*}{$\begin{array}{c}\% \\
\text { reduction } \\
\text { in F1 } \\
\text { progeny }\end{array}$} & \multirow{2}{*}{$\begin{array}{c}\text { \%loss } \\
\text { of } \\
\text { wheat } \\
\text { grain } \\
\text { weight }\end{array}$} \\
\hline & & $\begin{array}{c}1 \\
\text { week }\end{array}$ & $\begin{array}{c}2 \\
\text { weeks }\end{array}$ & $\begin{array}{c}1 \\
\text { week }\end{array}$ & $\begin{array}{c}2 \\
\text { weeks }\end{array}$ & & & \\
\hline Spinosad & $\begin{array}{c}10 \\
50 \\
100 \\
150 \\
\end{array}$ & $\begin{array}{l}38 \\
41 \\
86 \\
90\end{array}$ & $\begin{array}{l}57 \\
72 \\
93 \\
98\end{array}$ & 25 & 8.8 & $\begin{array}{c}93 \mathrm{de} \\
22.3 \mathrm{~g} \\
0.0 \\
0.0\end{array}$ & $\begin{array}{c}52.3 \mathrm{e} \\
88.5 \mathrm{c} \\
100 \mathrm{a} \\
100 \mathrm{a}\end{array}$ & $\begin{array}{c}13.6 \mathrm{e} \\
5.7 \mathrm{fg} \\
2.7 \mathrm{hij} \\
1.7 \mathrm{j}\end{array}$ \\
\hline Ivermectin & $\begin{array}{c}10 \\
50 \\
100 \\
150 \\
\end{array}$ & $\begin{array}{l}15 \\
28 \\
70 \\
85\end{array}$ & $\begin{array}{l}30 \\
43 \\
71 \\
95 \\
\end{array}$ & 56 & 26 & $\begin{array}{c}101.0 \mathrm{~d} \\
69.6 \mathrm{f} \\
14.3 \mathrm{gh} \\
0.0\end{array}$ & $\begin{array}{l}48.2 \mathrm{f} \\
64.3 \mathrm{~d} \\
92.6 \mathrm{~b} \\
100 \mathrm{a} \\
\end{array}$ & \begin{tabular}{|c|}
$16.1 \mathrm{~d}$ \\
$11.9 \mathrm{e}$ \\
$3.9 \mathrm{ghi}$ \\
$2.1 \mathrm{ij}$ \\
\end{tabular} \\
\hline Malathion & $\begin{array}{c}0.5 \\
1 \\
2 \\
4 \\
\end{array}$ & $\begin{array}{l}28 \\
40 \\
48 \\
56 \\
\end{array}$ & $\begin{array}{l}61 \\
73 \\
91 \\
95 \\
\end{array}$ & 2.4 & 0.23 & $\begin{array}{c}12.3 \mathrm{~h} \\
11.6 \mathrm{~h} \\
0.0 \\
0.0 \\
\end{array}$ & $\begin{array}{c}93.6 \mathrm{~b} \\
94.0 \mathrm{~b} \\
100 \mathrm{a} \\
100 \mathrm{a} \\
\end{array}$ & \begin{tabular}{|c|}
$7.5 \mathrm{f}$ \\
$4.3 \mathrm{gh}$ \\
$2.4 \mathrm{hij}$ \\
$1.3 \mathrm{j}$ \\
\end{tabular} \\
\hline Control & 0 & 0 & 0 & & & $195.0 \mathrm{a}$ & & $41.5 \mathrm{a}$ \\
\hline
\end{tabular}

Mean followed by the same letters in the column are not significantly different $(P<0.05)$.

Our results are in agreement with (Fang et al., 2002b) they found that spinosad, as a grain protectant, is highly effevtive against a very of stored product insects. Spinosad residues applied to indoor surfaces, such as those found in empty bins, warehouses, retail stores and food processing facilities, may persistent and exert insecticidal activity for extended periods (Toews et al,. 2003). Many research workers investigated the effectiveness of spinosad, ivermectin and malathion against some important of stored product insects (Abo-Arab and El-Hamady, 1998; Nayak et al.,2005; Kljajic and Peric, 2007; Athanassiou et al. 2009; Fouad,2013 and Gonzalez et al., 2014). Daglish et al. (2003) suggested that an application rate of $1 \mathrm{mg} / \mathrm{kg}$ spinosad in wheat may be suitable for controlling R.dominica strains that are resistant to organophosphates, pyrethroids or the insect growth regulator, methoprene. Subramanyam et al. (2007) demonstrated that a single application of spinosad at $1 \mathrm{mg} / \mathrm{kg}$ is effective for managing common stored grain insects including R.dominica for at least 6 months.

Effect of spinosad and ivermectin by modified mixing (mixture of untreated and treated wheat grain) on three tested insects :

To evaluate the modified method of mixing with media on mortality, emerged adults, reduction in F1 progeny and loss of wheat grain, a laboratory experiment was conducted, including three treatments, in the first, batches of wheat grain received the complete dose $(10,50,100$ and $150 \mathrm{ppm})$. In the second treatment, batches of wheat grain divided into two equal groups, the first group received the complete dose and mixed with the other untreated group to obtain final rate equal the half-dose. In the third treatment batched of wheat grain divided into three equal groups, one of them treated with the complete dose and mixed with the two untreated groups to obtain final rate equal the one-third dose. 


\section{Efficacy of nsecticides on F1 progeny of tested insects:}

Based on some of criteria (latent effect) number of emerged adults, reduction in F1 progeny and loss of wheat weight, in respect to, a laboratory experiment was carried out to evaluate the modified method of mixing with media mentioned before. Data obtained in Table (4) showed that S.oryzae adults exposed to wheat grain diet received half-dose of $10 \mathrm{ppm}$ spinosad or ivermectin, separately highly affected, where produced 233 and 172 adults in F1 progeny, respectively, compared to control which produced 427 adults in F1 progeny. The remained levels of spinosad or ivermectin almost completely prevented F1 progeny compared to the untreated treatment (control). For the one-third dose, results in Table(5) were similar to that of half-dose treatment where the low level of $10 \mathrm{ppm}$ greatly decreased the number of F1 progeny compared to control, while the high levels of both spinosad or ivermectin nearly completely prevented the $\mathrm{F} 1$ progeny of S.oryzae with \% reduction values of $(82.3,97.2,100 \%)$ and $(82.3,100,100 \%)$ at rates of 50,100 and $150 \mathrm{ppm}$ of spinosad and ivermectin, respectively. For R.dominica, with the wheat grain diet which received either half or one-third dose, results obtained in Tables (6 and 7) cleared that R.dominica was highly affected than S.oryzae at the same levels of spinosad and ivermectin where spinosad at the all levels of half-dose completely prevented the F1 progeny of $R$.dominica while with the one-third dose the \% reduction values ranged from 82.3 to $100 \%$. To what limit, ivermectin had low effect on R.dominica compared to spinosad where its half-dose values achieved \% reduction of progeny rates ranged from 76.6 to $100 \%$, while the one-third dose rates (10-150 ppm) exhibited $\%$ reduction values ranged from 54.4 to $100 \%$. These fining parallel the results of initial kill (\% mortality) in Tables (6 and 7$)$. Results tabulated in Tables (4 to 7) concerned to the effect of tested doses (half and one-third dose) of spinosad or ivermectin on loss of whaet grain by S.oryzae or R.dominica demonstrated that the all rates of tested biocides greatly decreased the percent loss of wheat grain compared to control and these loss values parallel with the \% reduction of $\mathrm{F} 1$ progeny of both tested insect-species in this study.

Table (4): effect of half-dose treated media on S.oryzae adults at different exposure periods .

\begin{tabular}{|c|c|c|c|c|c|c|c|c|}
\hline \multirow[b]{2}{*}{ coumpounds } & \multirow{2}{*}{$\begin{array}{l}\text { Conc. } \\
\text { (ppm) }\end{array}$} & \multicolumn{2}{|c|}{\begin{tabular}{|c|}
$\begin{array}{c}\text { \%Mortality } \\
\text { after }\end{array}$ \\
\end{tabular}} & \multicolumn{2}{|c|}{$\mathrm{LC}_{50}$} & \multirow{2}{*}{$\begin{array}{c}\text { No. of } \\
\text { emerged } \\
\text { adults } \\
\text { after } 2 \\
\text { months }\end{array}$} & \multirow{2}{*}{$\begin{array}{c}\% \\
\text { reduction } \\
\text { in F1 } \\
\text { progeny }\end{array}$} & \multirow{2}{*}{$\begin{array}{c}\% \text { loss o } \\
\text { wheat } \\
\text { grain } \\
\text { weight }\end{array}$} \\
\hline & & $\begin{array}{c}1 \\
\text { week }\end{array}$ & $\begin{array}{c}2 \\
\text { weeks }\end{array}$ & $\begin{array}{c}1 \\
\text { week }\end{array}$ & $\begin{array}{c}2 \\
\text { weeks }\end{array}$ & & & \\
\hline Spinosad & $\begin{array}{c}10 \\
50 \\
100 \\
150\end{array}$ & $\begin{array}{l}26 \\
73 \\
85 \\
95\end{array}$ & $\begin{array}{c}29 \\
96 \\
96 \\
100\end{array}$ & 23 & 18 & $\begin{array}{c}233 \mathrm{~b} \\
0.0 \\
0.0 \\
0.0\end{array}$ & $\begin{array}{l}45.4 \mathrm{~d} \\
100 \mathrm{a} \\
100 \mathrm{a} \\
100 \mathrm{a}\end{array}$ & $\begin{array}{c}8.3 \mathrm{~b} \\
3.3 \mathrm{~d} \\
2.3 \mathrm{de} \\
1.2 \mathrm{e}\end{array}$ \\
\hline Ivermectin & $\begin{array}{c}10 \\
50 \\
100 \\
150 \\
\end{array}$ & $\begin{array}{l}38 \\
63 \\
86 \\
95\end{array}$ & $\begin{array}{c}56 \\
88 \\
96 \\
100\end{array}$ & 19 & 8 & $\begin{array}{c}172 \mathrm{c} \\
14.3 \mathrm{~d} \\
0.0 \\
0.0\end{array}$ & $\begin{array}{c}59.7 \mathrm{c} \\
96.6 \mathrm{~b} \\
100 \mathrm{a} \\
100 \mathrm{a}\end{array}$ & $\begin{array}{l}7.9 \mathrm{~b} \\
6.2 \mathrm{c} \\
3.0 \mathrm{~d} \\
2.1 \mathrm{de}\end{array}$ \\
\hline Control & 0 & 0 & 0 & & & $427 a$ & & $72.6 \mathrm{a}$ \\
\hline
\end{tabular}

Mean followed by the same letters in the column are not significantly different $(P<0.05)$. 
Table (5): Effect of one-third dose treated media on S.oryzae adults at different indicated periods.

\begin{tabular}{|c|c|c|c|c|c|c|c|c|}
\hline \multirow[b]{2}{*}{ Treatment } & \multirow[b]{2}{*}{ Conc.(ppm) } & \multicolumn{2}{|c|}{$\begin{array}{c}\begin{array}{c}\% \text { Mortality } \\
\text { after }\end{array} \\
\end{array}$} & \multicolumn{2}{|c|}{$\mathrm{LC}_{50}$} & \multirow{2}{*}{\begin{tabular}{|c} 
No. of \\
emerged \\
adults \\
after 2 \\
months
\end{tabular}} & \multirow{2}{*}{$\begin{array}{c}\% \\
\text { reduction } \\
\text { in F1 } \\
\text { progeny }\end{array}$} & \multirow{2}{*}{$\begin{array}{c}\begin{array}{c}\% \text { loss } \\
\text { of } \\
\text { wheat } \\
\text { grain } \\
\text { weight }\end{array} \\
\end{array}$} \\
\hline & & $\begin{array}{c}1 \\
\text { week }\end{array}$ & $\begin{array}{c}2 \\
\text { weeks }\end{array}$ & $\begin{array}{c}1 \\
\text { week }\end{array}$ & $\begin{array}{c}2 \\
\text { weeks }\end{array}$ & & & \\
\hline Spinosad & $\begin{array}{c}10 \\
50 \\
100 \\
150\end{array}$ & $\begin{array}{l}10 \\
80 \\
90 \\
95\end{array}$ & $\begin{array}{c}46 \\
90 \\
96 \\
100\end{array}$ & 28 & 11 & $\begin{array}{c}283.6 \mathrm{~b} \\
124.6 \mathrm{~d} \\
19.3 \mathrm{e} \\
0.0\end{array}$ & $\begin{array}{c}59.9 \mathrm{~d} \\
82.3 \mathrm{~b} \\
97.2 \mathrm{ab} \\
100 \mathrm{a}\end{array}$ & $\mid \begin{array}{c}16.3 \mathrm{~b} \\
4.0 \mathrm{~d} \\
2.6 \mathrm{ef} \\
1.8 \mathrm{f}\end{array}$ \\
\hline Ivermectin & $\begin{array}{c}10 \\
50 \\
100 \\
150\end{array}$ & $\begin{array}{l}18 \\
35 \\
55 \\
71\end{array}$ & $\begin{array}{l}41 \\
63 \\
83 \\
96\end{array}$ & 70 & 17 & $\begin{array}{c}229.0 \mathrm{c} \\
124.6 \mathrm{~d} \\
0.0 \\
0.0\end{array}$ & $\begin{array}{l}67.6 \mathrm{c} \\
82.3 \mathrm{~b} \\
100 \mathrm{a} \\
100 \mathrm{a}\end{array}$ & $\begin{array}{c}7.6 \mathrm{c} \\
4.0 \mathrm{~d} \\
2.5 \mathrm{ef} \\
2.2 \mathrm{f}\end{array}$ \\
\hline Control & 0 & 0 & 0 & & & $707.3 a$ & & $70.4 a$ \\
\hline
\end{tabular}

Mean followed by the same letters in the column are not significantly different $(P<0.05)$.

Table (6): Effect of half-dose treated media on R.dominica adults at different indicated periods.

\begin{tabular}{|c|c|c|c|c|c|c|c|c|}
\hline \multirow{2}{*}{ Treatment } & \multirow[b]{2}{*}{ Conc.(ppm) } & \multicolumn{2}{|c|}{$\begin{array}{c}\% \text { Mortality } \\
\text { after }\end{array}$} & \multicolumn{2}{|c|}{$\mathrm{LC}_{50}$} & \multirow{2}{*}{$\begin{array}{c}\text { No. of } \\
\text { emerged } \\
\text { adults } \\
\text { after } 2 \\
\text { months }\end{array}$} & \multirow{2}{*}{$\begin{array}{c}\% \\
\text { reduction } \\
\text { in F1 } \\
\text { progeny }\end{array}$} & \multirow{2}{*}{$\begin{array}{c}\% \text { loss } \\
\text { of } \\
\text { wheat } \\
\text { grain }\end{array}$} \\
\hline & & $\begin{array}{c}1 \\
\text { week }\end{array}$ & $\begin{array}{c}2 \\
\text { weeks }\end{array}$ & $\begin{array}{c}1 \\
\text { week }\end{array}$ & $\begin{array}{c}2 \\
\text { weeks }\end{array}$ & & & \\
\hline Spinosad & $\begin{array}{c}10 \\
50 \\
100 \\
150\end{array}$ & $\begin{array}{c}78 \\
95 \\
100 \\
100\end{array}$ & $\begin{array}{c}90 \\
98 \\
100 \\
100\end{array}$ & 3.3 & 0.47 & $\begin{array}{l}0.0 \\
0.0 \\
0.0 \\
0.0\end{array}$ & $\begin{array}{l}100 a \\
100 a \\
100 a \\
100 a\end{array}$ & \begin{tabular}{|c|}
$3.2 \mathrm{c}$ \\
$2.1 \mathrm{de}$ \\
$1.1 \mathrm{f}$ \\
$1.0 \mathrm{f}$
\end{tabular} \\
\hline Ivermectin & $\begin{array}{c}10 \\
50 \\
100 \\
150\end{array}$ & $\begin{array}{l}48 \\
68 \\
85 \\
98\end{array}$ & $\begin{array}{c}86 \\
94 \\
100 \\
100\end{array}$ & 13 & 1.1 & $\begin{array}{c}77.3 \mathrm{~b} \\
6.3 \mathrm{c} \\
0.0 \\
0.0\end{array}$ & $\begin{array}{c}76.6 \mathrm{c} \\
98.0 \mathrm{~b} \\
100 \mathrm{a} \\
100 \mathrm{a}\end{array}$ & \begin{tabular}{|c|}
$11.0 \mathrm{~b}$ \\
$2.9 \mathrm{~cd}$ \\
$3.1 \mathrm{c}$ \\
$1.9 \mathrm{ef}$
\end{tabular} \\
\hline ontrol & 0 & 0 & 0 & & & $331 \mathrm{a}$ & & $75.1 \mathrm{a}$ \\
\hline
\end{tabular}


Table (7): Effect of one-third dose treated media on R.dominica adults at different indicated periods .

\begin{tabular}{|c|c|c|c|c|c|c|c|c|}
\hline \multirow[b]{2}{*}{ Treatment } & \multirow[b]{2}{*}{ Conc.(ppm) } & \multicolumn{2}{|c|}{$\begin{array}{c}\text { \%Mortality } \\
\text { after }\end{array}$} & \multicolumn{2}{|c|}{$\mathrm{LC}_{50}$} & \multirow{2}{*}{$\begin{array}{c}\text { No. of } \\
\text { emerged } \\
\text { adults } \\
\text { after } 2 \\
\text { months }\end{array}$} & \multirow{2}{*}{$\begin{array}{c}\% \\
\text { reduction } \\
\text { in F1 } \\
\text { progeny }\end{array}$} & \multirow{2}{*}{\begin{tabular}{|c|}
$\begin{array}{c}\% \text { loss } \\
\text { of } \\
\text { wheat } \\
\text { grain } \\
\text { weight }\end{array}$ \\
\end{tabular}} \\
\hline & & $\begin{array}{c}1 \\
\text { week }\end{array}$ & $\begin{array}{c}2 \\
\text { weeks }\end{array}$ & $\begin{array}{c}1 \\
\text { week }\end{array}$ & $\begin{array}{c}2 \\
\text { weeks }\end{array}$ & & & \\
\hline Spinosad & $\begin{array}{c}10 \\
50 \\
100 \\
150\end{array}$ & $\begin{array}{l}58 \\
80 \\
88 \\
95\end{array}$ & $\begin{array}{c}75 \\
91 \\
100 \\
100\end{array}$ & 7.0 & 3.4 & $\begin{array}{c}16.6 \mathrm{~d} \\
13.0 \mathrm{e} \\
0.0 \\
0.0\end{array}$ & $\begin{array}{l}82.3 \mathrm{~b} \\
98.0 \mathrm{a} \\
100 \mathrm{a} \\
100 \mathrm{a}\end{array}$ & \begin{tabular}{|l|}
$7.1 \mathrm{~d}$ \\
$3.1 \mathrm{ef}$ \\
$2.6 \mathrm{f}$ \\
$1.9 \mathrm{f}$
\end{tabular} \\
\hline Ivermectin & $\begin{array}{c}10 \\
50 \\
100 \\
150 \\
\end{array}$ & $\begin{array}{l}33 \\
66 \\
81 \\
95\end{array}$ & $\begin{array}{c}41 \\
78 \\
96 \\
100\end{array}$ & 21 & 14 & $\begin{array}{c}29.9 \mathrm{~b} \\
20.5 \mathrm{c} \\
20.6 \mathrm{e} \\
0.0\end{array}$ & $\begin{array}{l}54.4 \mathrm{~d} \\
86.7 \mathrm{c} \\
96.8 \mathrm{a} \\
100 \mathrm{a}\end{array}$ & \begin{tabular}{|l|}
$29.8 \mathrm{~b}$ \\
$12.3 \mathrm{c}$ \\
$4.6 \mathrm{e}$ \\
$2.7 \mathrm{ef}$ \\
\end{tabular} \\
\hline Control & 0 & 0 & 0 & & & $659.0 \mathrm{a}$ & & $79.6 \mathrm{a}$ \\
\hline
\end{tabular}

Mean followed by the same letters in the column are not significantly different $(P<0.05)$.

Table (8): Comparative mortality produced from two different methods of mixing with media at two periods of exposure .

\begin{tabular}{|c|c|c|c|c|c|c|c|c|}
\hline \multirow{3}{*}{ Insects } & \multirow{3}{*}{ Insecticides } & \multirow{3}{*}{$\begin{array}{l}\text { Conc. } \\
\text { (ppm) }\end{array}$} & \multicolumn{3}{|c|}{ \%mortality (1 week) } & \multicolumn{3}{|c|}{ \%mortality (2 weeks) } \\
\hline & & & \multirow{2}{*}{$\begin{array}{c}\begin{array}{c}\text { Common } \\
\text { type }\end{array} \\
\begin{array}{c}\text { Complete } \\
\text { dose }\end{array}\end{array}$} & \multicolumn{2}{|c|}{ Modified type } & \multirow{2}{*}{$\begin{array}{c}\begin{array}{c}\text { Common } \\
\text { type }\end{array} \\
\begin{array}{c}\text { Complete } \\
\text { dose }\end{array}\end{array}$} & \multicolumn{2}{|c|}{ Modified type } \\
\hline & & & & $\begin{array}{l}\text { Half- } \\
\text { dose }\end{array}$ & $\begin{array}{l}\text { One- } \\
\text { third } \\
\text { dose }\end{array}$ & & $\begin{array}{l}\text { Half- } \\
\text { dose }\end{array}$ & $\begin{array}{l}\text { One- } \\
\text { third } \\
\text { dose }\end{array}$ \\
\hline \multirow{10}{*}{ R.dominica } & & 0 & 0 & 0 & 0 & 0 & 0 & 0 \\
\hline & & 10 & 63 & 78 & 58 & 81 & 90 & 75 \\
\hline & Spinosad & 50 & 81 & 95 & 80 & 86 & 98 & 91 \\
\hline & & 100 & 86 & 100 & 88 & 96 & 100 & 100 \\
\hline & & 150 & 100 & 100 & 95 & 100 & 100 & 100 \\
\hline & & 0 & 0 & 0 & 0 & 0 & 0 & 0 \\
\hline & & 10 & 75 & 48 & 33 & 83 & 86 & 41 \\
\hline & Ivermectin & 50 & 85 & 68 & 66 & 91 & 94 & 78 \\
\hline & & 100 & 95 & 85 & 81 & 98 & 100 & 96 \\
\hline & & 150 & 96 & 98 & 95 & 100 & 100 & 100 \\
\hline \multirow{10}{*}{ S.oryzae } & & 0 & 0 & 0 & 0 & 0 & 0 & 0 \\
\hline & & 10 & 40 & 26 & 10 & 46 & 29 & 46 \\
\hline & Spinosad & 50 & 63 & 73 & 73 & 79 & 96 & 90 \\
\hline & & 100 & 78 & 85 & 90 & 94 & 96 & 96 \\
\hline & & 150 & 93 & 95 & 95 & 100 & 100 & 100 \\
\hline & & 0 & 0 & 0 & 0 & 0 & 0 & 0 \\
\hline & & 10 & 45 & 38 & 18 & 61 & 56 & 41 \\
\hline & Ivermectin & 50 & 76 & 63 & 35 & 88 & 88 & 63 \\
\hline & & 100 & 88 & 86 & 55 & 100 & 96 & 83 \\
\hline & & 150 & 100 & 95 & 71 & 100 & 100 & 96 \\
\hline
\end{tabular}

Mean followed by the same letters in the column are not significantly different $(P<0.05)$.

From the results summarized in Table (8) the following aspects were observed.

1- At the low level of $10 \mathrm{ppm}$ spinosad or ivermectin there was a different effect (on \% mortality) on both tested insects between the three tested doses, complete, half and the one-third dose mixed with media where level of $10 \mathrm{ppm}$ ivermectin achieved 75,48 and $33 \%$ mortality with mentioned doses, respectively, for R.dominica . 
2- Results also showed that when the levels of tested biocides, spinosad and ivermectin increased the differences between mortality ratios resulted from the effect of the tested doses decreased, where the levels of 100 or 150 ppm ivermectin or spinosad exhibited nearly equal effectiveness (as $\%$ mortality) with the three tested does against R.dominica at the two periods of exposure. For S.oryzae the results demonstrated the same trend either with the low level $(10 \mathrm{ppm})$ or with the high levels (100 and $150 \mathrm{ppm}$ ) of spinosad or ivermectin at the two periods of exposure.

3- These results established that the type of treatment plays an important role in improving the effect of tested materials, since the modified method of mixing with media (mixture of treated and untreated wheat grain) arised the efficacy of the tested biocides where this method reduced the levels required to give high mortality percentages. In contrast, using the common method, mixing with media (complete dose mixed with the all wheat grain) requires high concentrations to gain high mortality. Porbability, this success of the modified method in achieving high mortality by low concentration will be dependent on the mobility of insects either upword or downword through the treated and untreated wheat grain to pick the dose required to achieve high insect mortality. On the other side, use of common mixing with media restricts the mortality of insects to avoid the contact with treated media. Athanassiou et al. (2009) showed that while spinosad has some effectiveness as a layer treatment on column of wheat, efficacy will be dependent on the target species, the depth of the treated layer, and the upward or downward mobility of the insect species.

4- The present results show that modified method of mixing with media is likely to be an effective method for grain protection against R.dominica and S.oryzae in mixture of treated and untreated media.

\section{REFERENCES}

Abbott, W.W. (1925). A method of computing the effectiveness of an insecticide. J. Econ.Entomol.18: 265-267.

Abo-Arab-R.B.S. and Sh.E.E. El-Hamady (1998). Ivermectin as a protectant against stored grain insects. Alex. Sci. Exch.19: 419-427.

Andrie,G. Kljajic, P., and Prazie Golie, M.(2011). Effects of spinosad and abamactin different populations of rice weevil Sitophilus oryzae (L.) in treated wheat grain. Pesticides and phytomedicin, 26(4): 377-384.

Arthur, F.H., Yue,B., and Wilde,G.E. (2004). Susceptibility of stored product beetles on wheat and maize treated with thiamethoxam: effects of concentration, exposure interval, and temperature. J. of stored. Prod. Res, 40 (5), $527-546$.

Athanassiou, Ch.G; F.H. Arthur and J.E. Throne (2009). Efficacy of spinosad in layer-treated wheat against five stored-product insect species.J.Stored Prod. Res.45 (4): 236-240. 
Athanassiou, C.G., Kavallierators, N.G, Yiatilis, A.E., Vayias, B.J., Mavrotas, C.S., and Tomanovic, Z. (2008). Influence of temperature and humidity on the efficacy of spinosad against four stored grain beetles species. J. of. Insect Science, 8, 1-9.

Bret BL, Larson LL, Schoonover JR, Sparks TC, Thompson GD (1997) Biological properties of spinosad. Down Earth 52:6-13.

Copping,L.G. andMenn.(2002).Biobesticides a review of their action,application and efficacy.Pest.Manage.sci.,56:651-676.

Daglish G J and M .K. Nayak (2006). Long term persistence and efficacy of spinosad against Rhyzopertha dominica (Coleoptera: Bostrychidae) in wheat. Pest Manag. Sci., 62(2): 148-152.

Daglish, G.J.; M.K. Nayak and V.S.Byrne (2003). Is there a role for spinosad in protecting Australian grain from insects? Proceedings of the Australian Postharvest Technical Conference, Caberra, 25-27 June 2003. CSIRO Stored Grain Research Laboratory, Canberra, 78-81.

Duncan, D.B. (1955). multiple range and multiple F-test. biometrics. 11:1-42.

EL-Tawelah.N.M. (2005)., I ntegrated control of some stored grain pests. Master of science Agric.Tanta., Univ.

Fang, L.; S.Bhadriraju and D.Sean (2002a). Persistence and efficacy of spinosad residues in farm stored wheat. J.Econ. Entomol. 95 (5): 1102-1109.

Fang L A. and Subramanyam B (2003b). Activity of spinosad adults of Rhyzopertha dominica (Fab.) (Coleoptera : Bostrichidae) is not affected by wheat temperature and moisture. J. Kansas. Entomol. Soci., 76(3): 529-532.

Fang, L; Subranyam, Bh; and Arthur, F.H, (2002b). Effectiveness of spinosad on four classes of wheat against five stored product insects. J. of . Economic. Entomol .95, 640-650.

Fouad,H.A. (2013). Effect of five essential oils as repellent against the cowpea beetle, Callosobruchus maculates (F.). Bnulletin of Environment. Pharmacology and Life Sciences, 2(5): 23-27.

Gonzalez,J.O.W.; M.M.Gutierrz; A.A.Ferrero and B.F.Banol (2014). Essential oils nanoformulations for stored product pest control-characterization and biological properties chemosphere, 100: 130-138.

Harris, K. and C.S.Lindblad (1978). Postharvest grain loss assessment methods careal. Chem. St. Paul. M.N. 193 pp.

Kavallieratos, N.G., Athanassiou, C.G, Vayias, B.J., Minail, S.B., and Tomanovic, Z. (2009). Insecticidal efficacy of abamactin against three stored product insect pests: influence of dose rate, temperature, commodity, and exposure interval. J. of econ. Ent. 102 (3), 1352-1359. pmid : 19610457.

Kestenholz C., Philip C., Stevensona S., Belmain R. (2007). Comparative study of field and laboratory evaluations of the ethnobotanical Cassia sophera L. (Leguminosae) for bioactivity against the storage pests Callosobruchus maculatus (F.) (Coleoptera: Bruchidae) and Sitophilus oryzae (L.) (Coleoptera: Curculionidae). J. Stored Products Res. 43: 79-86

Kljajic, P. (2008). Suzbijanje Stetnih Insekata Uskladistenogzita. Inp-Kljajic (Ed.). Zastila Uskladisenih biljnib proizvo. Daodstenih organizama, (pp.67 - 100). Beograd: Institut. Za pesticide izastitu zivontes sredine. 
Kljajic, P. and I.Peric (2007). Effectiveness of wheat-applied contact insecticides against Sitophilus granaries (L.) originating from different populations.J.Stored Prod. Res. 43: 523-528.

Lessard F F, Vidaland M M. and Budzinski H (1998). Modeling biological efficacy decrease and rate of degradation of chlorpyrifos methyl on wheat stored under controlled condition. J.Stord Prod. Res., 34: 341-354.

MacBean, C. (2012). The pesticide manual $16^{\text {th }}$ edition UV: British crop protection council.

Mondal, K.A.M. and S.Parween (2000). Insect growth regulators and their potential in the management of stored product insect pests. Int Pest. Management. Rev. 52-55.

Nayak M.K.; G.J.Deglish and V.S.Byrne (2005). Effectiveness of spinosad as a grain protectant against resistant beetle and psocid pests of stored grain in Australia. J.Stored Prod.Res. 41 (4): 455-467.

Paoletti. MG; and Pimental,D. (2000). Environmental risks of pesticides versus genetic engineering for agricultural pest control.J. of Agric. And Environmental. Ethics. 12 : 279-303. Cross Ref.

Salgado VL (1998) Studies on the mode of action of spinosad: insect symptoms and physiological correlates. Pestic Biochem Physiol 60:91-102.

Shakoori A R, Saleem M A and Mantle D (1998). Some macromolecular Abnormalities induced by a sublethel dose of Cymbush $10 \mathrm{EC}$ in adult beetles of Triboliumcastaneum.Pakistan J. Zool., 30: 83-9

Subramanyam, B.; M.Toews; K.Ileleii; D. Maier; G.Thompson; and T.Pitts (2007). Evaluation of spinosad as a grain protectant on three Kansas farms. Crop Protection 26: 1021-1030.

Tapondjou,L.A., Adler,C., Bouda,H., and Fontem,D.A. (2002). Efficacy of powder and 17 essential oil from Chenopodium ambrosioides leaves as postharvest grain protectants 18 against six-stored product beetles. J.of st. Prod. Res. 38, 395-402. temperature and moisture. J. Kansas. Entomol. Soci., 76(3): 529-532.

Thomposon,G.D; R.Dutton and T.C. Sparks (2000). Spinosad a case study: an example from a natural products discovery programme. Pest Manag.Sci. 56: 696-702.

Toews, M.D.; B.Subramanyam and J.M.Rowan (2003). Knockdown and mortality of adults of eight species of stored-product beetles exposed to four surfaces treated with spinosad. J.Econ. Entomol. 96 (6): 1967-1973.

Wakil, W., Riasat, T.; and Lord, J.C (2013). Effects of combined thiamethoxam and diatomaceous earth on mortality and progeny production of four Pakistan. Populations of Ryzopertha dominica (Coleoptera: Bostrichidae) on wheat, rice and maize. J. of Stored Products Res, 52, 28-35.

White,N.D.G; and Leesch, J.G (1996). Chemical control. In subramanyam (B \& D.W.Hagstrum (Eds.), Integrated management of insects in stored products (pp : 287-330). New York, Basel, Hon Kong: Marcel Dekker. 


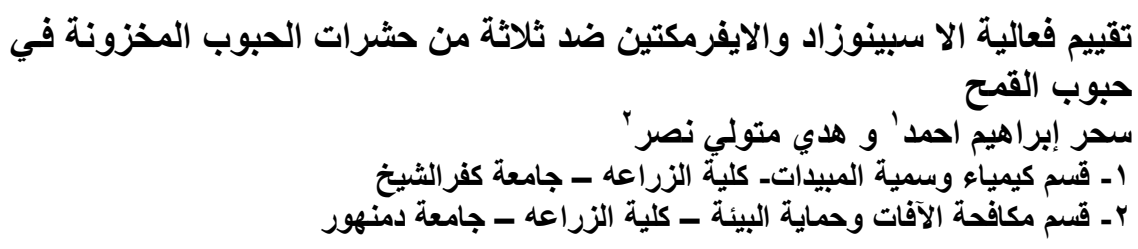

أجريت هذه الدر اسة بغرض تقييم مركبين و هما سبينوساد ، أفيرمكتين بجانب مبيد الملاثيون

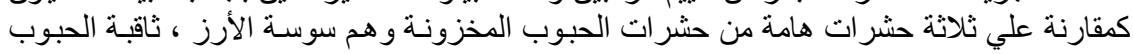

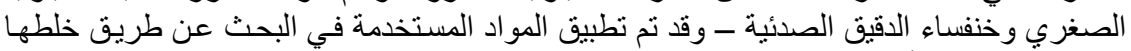

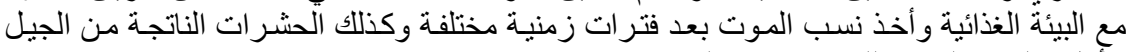

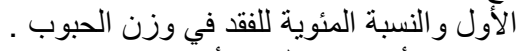

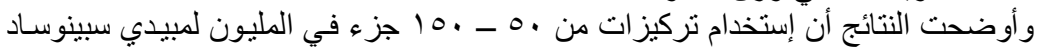

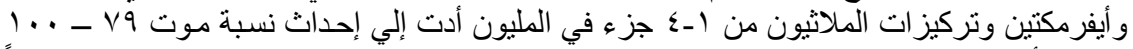

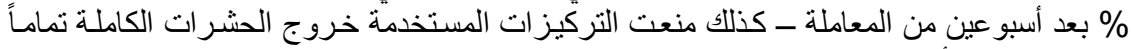

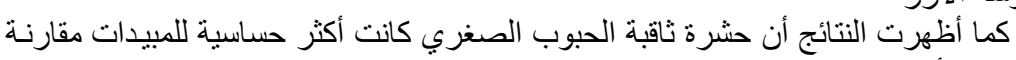

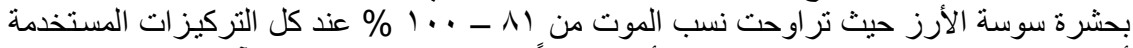

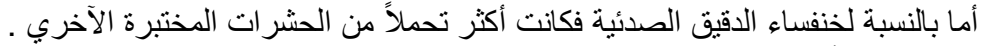

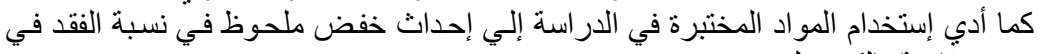

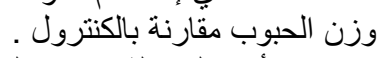

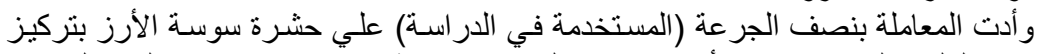

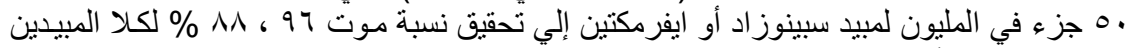

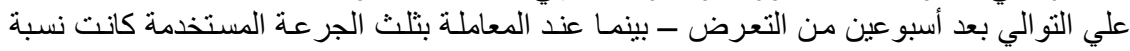

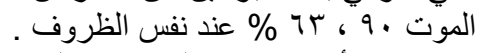

وأدي إستخدام التركيزات المرتفعه (0.0 ـ - 10 جزء في المليون) لكلا المبيدين إلي منع

$$
\text { وجود الخلفة تماماً. }
$$

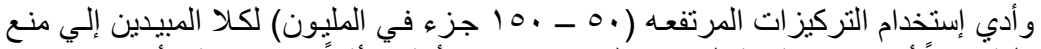

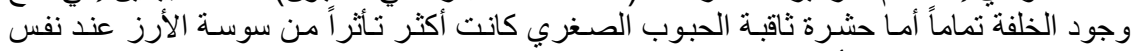

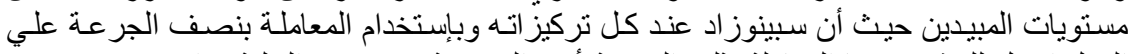

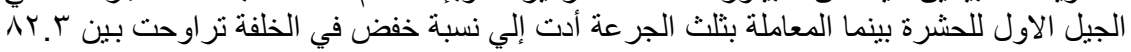

$$
\text { \% إلي ... \% }
$$

